\title{
Isolation and Biological Evaluation of Prenylated Flavonoids from Maclura pomifera
}

\author{
Yerkebulan Orazbekov, ${ }^{1,2}$ Mohamed A. Ibrahim, ${ }^{1,3}$ Serjan Mombekov, ${ }^{4}$ \\ Radhakrishnan Srivedavyasasri, ${ }^{1}$ Ubaidilla Datkhayev, ${ }^{4}$ Bauyrzhan Makhatov, ${ }^{2}$ \\ Narayan D. Chaurasiya, ${ }^{1}$ Babu L. Tekwani $\mathbb{D}^{1,5}$ and Samir A. Ross $\mathbb{D}^{1,5}$ \\ ${ }^{1}$ National Center for Natural Products Research, University of Mississippi, University, MS 38677, USA \\ ${ }^{2}$ South-Kazakhstan State Pharmaceutical Academy, Al-Farabi Square, Shymkent 160019, Kazakhstan \\ ${ }^{3}$ Department of Chemistry of Natural Compounds, National Research Center, Dokki, Cairo 12622, Egypt \\ ${ }^{4}$ Kazakh National Medical University, Almaty 050000, Kazakhstan \\ ${ }^{5}$ Department of Biomolecular Science, University of Mississippi, University, MS 38677, USA
}

Correspondence should be addressed to Samir A. Ross; sross@olemiss.edu

Received 21 September 2017; Accepted 9 December 2017; Published 14 January 2018

Academic Editor: Armando Zarrelli

Copyright (C) 2018 Yerkebulan Orazbekov et al. This is an open access article distributed under the Creative Commons Attribution License, which permits unrestricted use, distribution, and reproduction in any medium, provided the original work is properly cited.

\begin{abstract}
Phytochemical analysis of the ethanolic extract of Maclura pomifera fruits yielded four new compounds (I-IV) along with eleven known compounds ( V-XV). The crude extract exhibited significant activity towards cannabinoid receptors (CB1: 103.4\% displacement; CB2: $68.8 \%$ displacement) and possibly allosteric interaction with $\delta$ and $\mu$ opioid receptors $(-49.7$ and $-53.8 \%$ displacement, resp.). Compound I was found to be possibly allosteric for $\kappa$ and $\mu$ opioid receptors ( -88.4 and $-27.2 \%$ displacement, resp.) and showed moderate activity (60.5\% displacement) towards CB1 receptor. Compound II exhibited moderate activity towards cannabinoid receptors CB1 and CB2 (47.9 and 42.3\% displacement, resp.). The known compounds (V-VIII) exhibited prominent activity towards cannabinoid receptors: pomiferin (V) ( $\mathrm{IC}_{50}$ of 2.110 and $1.318 \mu \mathrm{M}$ for $\mathrm{CB} 1$ and $\mathrm{CB} 2$, resp.), auriculasin (VI) (IC 50 of $8.923 \mu \mathrm{M}$ for CB1), warangalone (VII) (IC 50 of 1.670 and $4.438 \mu \mathrm{M}$ for CB1 and CB2, resp.), and osajin (VIII) (IC 50 of 3.859 and $7.646 \mu \mathrm{M}$ for $\mathrm{CB} 1$ and $\mathrm{CB} 2$, resp.). The isolated compounds were also tested for inhibition of human monoamine oxidase-A and monoamine oxidase-B enzymes activities, where all the tested compounds showed fewer inhibitory effects on MAO-A compared to MAO-B activities: auriculasin (VI) ( $\mathrm{IC}_{50}$ of 1.91 and $45.98 \mu \mathrm{M}$ for MAO-B and MAO-A, resp.).
\end{abstract}

\section{Introduction}

Maclura pomifera L. (Maclura aurantiaca Syn., Moraceae family) is a native southwestern American plant commonly known as Osage orange. Osage orange typically grows in sunny areas and can grow in a wide range of soil conditions [1]. Worldwide, various Maclura species are used in folk medicine. Native Americans used M. pomifera for the treatment of cancer [2]. In Bolivia, the plant sap is used for the treatment of tooth pain, and the bark and leaves are used for uterine hemorrhage [3]. Comanche Indians in North America used the Osage orange roots decoction to treat sore eyes [4]. M. pomifera and its components possess several biological activities including cytotoxic, antitumor, antibacterial, estrogenic, antifungal, antiviral, and antimalarial activities [5-13]. Recently, isoflavones isolated from Osage orange have been demonstrated to protect brain cells, or neurons, from the toxic effect of amyloid beta peptide, which is believed to be responsible for the degeneration of neurons in Alzheimer's disease patients. However, the mechanisms by which isoflavones block the toxicity of amyloid beta peptide are unknown [14]. M. pomifera produces several secondary metabolites belonging to different chemical classes including prenylated flavonoids. The prenylated flavonoids possess different biological activities such as antifungal, antibacterial, antitumor, and antioxidant activities. The wide range of bioactivities of these compounds is attributed to the 
prenylation on the flavonoids, which in turn increases their lipophilicity and membrane permeability [15]. In this report, we have examined $M$. pomifera growing in Kazakhstan which has never been exposed to extensive phytochemical or biological studies. We present the isolation and characterization of four new and eleven known metabolites from the fruits of M. pomifera growing in Kazakhstan and their accompanying cannabinoid, opioid, and MAO receptors activities.

\section{Materials and Methods}

2.1. Apparatus, Materials, and Chemicals. A Bruker model AMX 500 NMR and 400 NMR spectrometers operating on a standard pulse system were used to acquire ${ }^{1} \mathrm{H}$ and ${ }^{13} \mathrm{C} \mathrm{NMR}$ and $2 \mathrm{D}$ spectra. The instruments ran at 500 and $400 \mathrm{MHz}$ for ${ }^{1} \mathrm{H}$ while they ran at 125 and $100 \mathrm{MHz}$ for ${ }^{13} \mathrm{C}$. $\mathrm{CDCl}_{3}, \mathrm{DMSO}-d_{6}$, and acetone- $d_{6}$ were used as NMR solvents, and TMS was used as an internal standard. ESIMS data were recorded on Thermo Orbitrap Fusion (Thermo Scientific). Samples were analyzed in the negative mode of ionization. Samples were directly infused at $3 \mathrm{uL} / \mathrm{min}$. Mass was analyzed in Orbitrap (mass error on the instrument $<2$ ppm). ESI-MS data were obtained on a Micromass QTof micromass spectrometer. FTMS-ESI was analyzed on Thermo Orbitrap Fusion (Thermo Scientific). The sample was analyzed in the negative mode of ionization. Mass was analyzed in Orbitrap (mass error on the instrument $<2 \mathrm{ppm}$ ). TLC was performed on precoated silica gel GF254 plates and Column Chromatography was performed on silica gel (200-300 mesh) and Sorbadex-LH20 (Sorbent Technologies, Atlanta, GA, USA). The recombinant human monoamine oxidase-A and monoamine oxidase-B enzymes were obtained from BD Biosciences (Bedford, MA, USA). Kynuramine, clorgyline, phenelzine, deprenyl, and DMSO were procured from Sigma Chemical Company (St. Louis, MO, USA).

2.2. Plant Material. Fresh fruits of M. pomifera (L.) $(20 \mathrm{Kg})$ were purchased from Shymkent, Kazakhstan, in October 2015. A voucher specimen of $M$. pomifera was identified by Dr. Kulpan Orynbasarova and deposited at the Department of Pharmacognosy and Chemistry, South-Kazakhstan State Pharmaceutical Academy, Shymkent, Kazakhstan, with an index number "MA-777."

2.3. Extraction and Isolation. Fresh fruits were cut into small pieces and macerated with ethanol $(2 \times 50 \mathrm{~L}, 48 \mathrm{~h}$ each $)$ at $25^{\circ} \mathrm{C}$. The combined extracts were concentrated under reduced pressure to yield crude extract $(1 \mathrm{Kg})$. The extract showed a yellow precipitate which was filtered and weighed $(85 \mathrm{~g})$. Eighty grams of the precipitate was loaded on silica gel and fractionated using DCM-MeOH gradient to yield 6 fractions (A1-A6). Fraction A1 (4g) was loaded on a silica gel column, where the elution was completed using DCM-MeOH gradient to yield stigmasterol (XIV, $15 \mathrm{mg}$ ) and $\beta$-sitosterol (XV, $20 \mathrm{mg}$ ). Fraction A2 (7 g) was loaded on Sorbadex-LH20 and eluted with $\mathrm{MeOH}-\mathrm{H}_{2} \mathrm{O}$ to yield pomiferin (V, $500 \mathrm{mg}$ ) [16], auriculasin (VI, $100 \mathrm{mg}$ ) [16], warangalone (VII, $50 \mathrm{mg}$ ) [17], and osajin (VIII, $500 \mathrm{mg}$ ) [16].
Chromatographic purification of fraction A3 (1.5 g) on Sorbadex-LH20 using $\mathrm{MeOH}-\mathrm{H}_{2} \mathrm{O}$ gradient yielded compound I (10 mg), compound II (5 mg), artocarpesin (IX, $7 \mathrm{mg}$ ) [16], compound III (10 mg), compound IV (7 mg), kaempferol-7-O- $\beta$-D-glucoside (XII, $8 \mathrm{mg}$ ) [16], dihydrokaempferol-7-O- $\beta$-D-glucoside (XIII, $10 \mathrm{mg}$ ) [16], tonkinensisol ( $\mathbf{X}, 5 \mathrm{mg})$ [18], and corchoionoside B (XI, $15 \mathrm{mg}$ ) [19]. The structures of the isolated compounds (Figure 1) were established using NMR (1D, 2D), IR, and mass spectral data.

2.3.1. 3-(3,4-Dihydroxyphenyl)-5-hydroxy-10-(3-hydroxy-2-methoxy-3-methylbutyl)-8,8-dimethylpyrano [3,2-g]chromen4(8H)-one (I), Named Kazosajin I. IR (neat) $\mathrm{cm}^{-1}: 2927$, 1593, 1250, 1120. HR-FTMS: $m / z[\mathrm{M}+\mathrm{Na}]^{+}$calcd. for $\mathrm{C}_{26} \mathrm{H}_{28} \mathrm{NaO}_{8}$ : 491.1682; found: 491.1690. ${ }^{1} \mathrm{H}$ NMR (500 MHz, DMSO-d6, Supporting Information (available here)): Table 1. ${ }^{13} \mathrm{C}$ NMR (125 MHz, DMSO-d6, Supporting Information (available here)): Table 2.

2.3.2. 3-(3,4-Dihydroxyphenyl)-5-hydroxy-6-(2-hydroxy-3methylbut-3-enoyl)-8,8-dimethylpyrano[2,3-f]chromen4(8H)-one (II), Named Kazosajin II. IR (neat) $\mathrm{cm}^{-1}: 2927$, 1649, 1438, 1263, $1120 \mathrm{~cm}^{-1}$. HR-FTMS: $m / z[\mathrm{M}-\mathrm{H}]^{-}$calcd. for $\mathrm{C}_{25} \mathrm{H}_{23} \mathrm{O}_{8}$ : 451.1393; found: 451.1415. ${ }^{1} \mathrm{H}$ NMR (500 MHz, DMSO-d6, Supporting Information (available here)): Table 1. ${ }^{13} \mathrm{C}$ NMR (125 MHz, DMSO-d6, Supporting Information (available here)): Table 2.

2.3.3. 11-Hydroxy-7-(4-hydroxyphenyl)-2,2,10,10-tetramethyl11,12-dihydro-2H-dipyrano[2,3-f: $2^{\prime}, 3^{\prime}$-h]chromen- $8(10 H)$-one (III), Named Kazosajin III. IR (neat) $\mathrm{cm}^{-1}: 2927,1647,1578$, 1438, 1258, 1194, 1118. HR-FTMS: $m / z[\mathrm{M}+\mathrm{H}]^{+}$calcd. for $\mathrm{C}_{25} \mathrm{H}_{25} \mathrm{O}_{6}$ : 421.1651; found: 421.1649. ${ }^{1} \mathrm{H} \mathrm{NMR}(500 \mathrm{MHz}$, DMSO-d6, Supporting Information (available here)): Table 1.

${ }^{13} \mathrm{C}$ NMR (125 MHz, DMSO-d6, Supporting Information (available here)): Table 2.

2.3.4. 3-(3,4-Dihydroxyphenyl)-10-((3,3-dimethyloxiran-2yl)(methoxy)methyl)-5-hydroxy-8,8-dimethylpyrano [3,2g]chromen-4(8H)-one (IV), Named Kazosajin IV. IR (neat) $\mathrm{cm}^{-1}: 2926,1632,1584,1435,1248,1138$. HR-FTMS: $\mathrm{m} / z$ $[\mathrm{M}-\mathrm{H}]^{-}$calcd. for $\mathrm{C}_{26} \mathrm{H}_{25} \mathrm{O}_{8}$ : 465.1549; found: 465.1466 . ${ }^{1} \mathrm{H}$ NMR (400 MHz, DMSO-d6, Supporting Information (available here)): Table 1. ${ }^{13} \mathrm{C}$ NMR (100 MHz, DMSO-d6, Supporting Information (available here)): Table 2.

2.4. Cannabinoid and Opioid Receptor Assay. The affinities of the total extracts and the isolated compounds towards cannabinoid and opioid receptors were assessed according to the published method [20].

2.5. MAO-A and MAO-B Inhibition Assay. The inhibitory effects of the chemical components of $M$. pomifera (L.) on MAO-A and MAO-B were determined via the kynuramine deamination assay, where it was adapted for 96-well plates as described earlier [21, 22]. A fixed concentration of the 
<smiles>COC(=Cc1c2c(c(O)c3c(=O)c(-c4ccc(O)c(O)c4)coc13)C=CC(C)(C)O2)C(C)(C)O</smiles>

(I)<smiles>COC(=C1OC1(C)C)c1c2c(c(O)c3c(=O)c(-c4ccc(O)c(O)c4)coc13)C=CC(C)(C)O2</smiles>

(IV)<smiles>CC(C)=CCc1c2c(c(O)c3c(=O)c(-c4ccc(O)cc4)coc13)C=CC(C)(C)O2</smiles>

(VII)

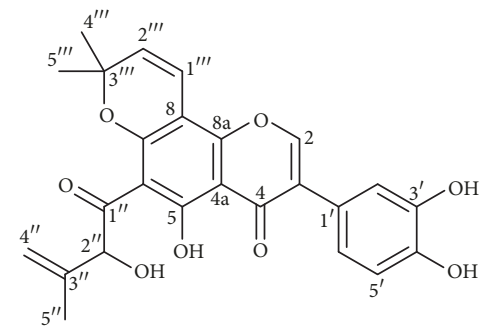

(II)<smiles>CC(C)=CCc1c2c(c3occ(-c4ccc(O)c(O)c4)c(=O)c3c1O)C=CC(C)(C)O2</smiles>

(V)<smiles>CC(C)=CCc1c2c(c3occ(-c4ccc(O)cc4)c(=O)c3c1O)C=CC(C)(C)O2</smiles>

(VIII)<smiles>CC1(C)C=Cc2c(c3c(c4c(=O)c(-c5ccc(O)cc5)coc24)OC(C)(C)C(O)C3)O1</smiles>

(III)<smiles>CC(C)=CCc1c2c(c(O)c3c(=O)c(-c4ccc(O)c(O)c4)coc13)C=CC(C)(C)O2</smiles>

(VI)<smiles>CC(C)=CCc1c(O)cc2oc(-c3cc(O)cc(O)c3)cc(=O)c2c1O</smiles>

(IX)<smiles>CC(C)=CCc1c2c(c(O)c3c(=O)c(O)c(-c4ccc(O)cc4)oc13)C=CC(C)(C)O2</smiles>

$(\mathrm{X})$<smiles>CC1=CC(=O)CC(C)(C)[C@@]1(O)/C=C/C(C)O/C(O)=C/C(=O)O</smiles>

(XI)

Figure 1: Structures of the selected compounds from M. pomifera.

substrate and varying concentrations of the inhibitor were used to determine the $\mathrm{IC}_{50}$ value at the point where $50 \%$ inhibition of the catalytic activity of the enzyme occurred. For MAO-A, the substrate (kynuramine) concentration of $80 \mu \mathrm{M}$ was chosen, since the $K_{M}$ value of substrate binding reported previously was approximately $40 \mu \mathrm{M}$ [23]. $K_{M}$ is the substrate concentration at half $V$ max; therefore, $2 \times K_{M}$ $(2 \times 40=80 \mu \mathrm{M})$ was selected for determining the $\mathrm{IC}_{50}$ values. Similarly, for MAO-B, a substrate (kynuramine) concentration of $50 \mu \mathrm{M}$ was chosen. The assay was performed with the addition of the inhibitor. Inhibition was calculated as percent of the product formation compared to the corresponding control (enzyme-substrate reaction) without the inhibitors. The enzyme reactions were carried out in $0.1 \mathrm{M}$ potassium phosphate buffer at $\mathrm{pH}$ 7.4. Reaction mixtures contained $5 \mu \mathrm{g} / \mathrm{mL}$ of MAO-A (18.75 $\mu \mathrm{L}$ in buffer) and $10 \mu \mathrm{g} / \mathrm{mL}$ of MAO-B $(18.75 \mu \mathrm{L}$ in buffer). The compounds were dissolved in DMSO and diluted in buffer. The total reaction mixture volume was $75 \mu \mathrm{L}$, yielding a final DMSO concentration of $1.0 \%$ in the reaction mixture. The reaction mixtures were preincubated for $10 \mathrm{~min}$ at $37^{\circ} \mathrm{C}$ followed by the addition of MAO-A/MAO-B to initiate the reactions. The reaction 
TABLE 1: ${ }^{1}$ H NMR data of compounds I-IV.

\begin{tabular}{|c|c|c|c|c|}
\hline Proton & ${ }^{\mathrm{a}}$ Compound I & ${ }^{\mathrm{a}}$ Compound II & ${ }^{\mathrm{a}}$ Compound III & ${ }^{\mathrm{b}}$ Compound IV \\
\hline 2 & $8.37(\mathrm{~s})$ & $8.31(\mathrm{~s})$ & $8.10(\mathrm{~s})$ & $8.42(\mathrm{~s})$ \\
\hline $2^{\prime}$ & $6.76(\mathrm{~m})$ & $7.00(\mathrm{~s})$ & $6.79(\mathrm{~d}, 8.4)$ & $6.81(\mathrm{~s})$ \\
\hline $3^{\prime}$ & - & - & $7.30(\mathrm{~d}, 8.4)$ & - \\
\hline $5^{\prime}$ & $6.99(\mathrm{~s})$ & $6.93(\mathrm{~d}, 1.8)$ & $7.30(\mathrm{~d}, 8.4)$ & $7.03(\mathrm{~d}, 1.9)$ \\
\hline $6^{\prime}$ & $6.76(\mathrm{~m})$ & $6.79(\mathrm{~d}, 1.8)$ & $6.79(\mathrm{~d}, 8.4)$ & $6.80(\mathrm{~d}, 1.9)$ \\
\hline $1^{\prime \prime}$ & $6.63(\mathrm{~d}, 10.0)$ & - & $2.79(\mathrm{dd}, 5.6,17.0), 2.43(\mathrm{dd}, 5.6,17.0)$ & $6.63(\mathrm{~d}, 10.0)$ \\
\hline $2^{\prime \prime}$ & $5.78(\mathrm{~d}, 10.0)$ & $4.52(\mathrm{~s})$ & $3.66(\mathrm{dd}, 5.6,7.1)$ & $5.82(\mathrm{~d}, 10.0)$ \\
\hline $4^{\prime \prime}$ & $1.43(\mathrm{~s})$ & $4.77(\mathrm{~s}), 4.67(\mathrm{~s})$ & $1.30(\mathrm{~s})$ & $1.44(\mathrm{~s})$ \\
\hline $5^{\prime \prime}$ & $1.41(\mathrm{~s})$ & $1.74(\mathrm{~s})$ & $1.20(\mathrm{~s})$ & $1.43(\mathrm{~s})$ \\
\hline $1^{\prime \prime \prime}$ & $2.75(\mathrm{~d}, 5.4)$ & $5.77(\mathrm{~d}, 10.0)$ & $5.73(\mathrm{~d}, 9.9)$ & $4.54(\mathrm{~d}, 7.3)$ \\
\hline $2^{\prime \prime \prime}$ & $3.47(\mathrm{~m})$ & $6.66(\mathrm{~d}, 10.0)$ & $6.68(\mathrm{~d}, 9.9)$ & $3.65(\mathrm{~d}, 7.3)$ \\
\hline $4^{\prime \prime \prime}$ & $1.13(\mathrm{~s})$ & $1.46(\mathrm{~s})$ & $1.45(\mathrm{~s})$ & 1.19 (s) \\
\hline $5^{\prime \prime \prime}$ & $1.21(\mathrm{~s})$ & $1.46(\mathrm{~s})$ & $1.44(\mathrm{~s})$ & $1.06(\mathrm{~s})$ \\
\hline $\mathrm{OMe}$ & $3.19(\mathrm{~s})$ & - & - & $3.22(\mathrm{~s})$ \\
\hline
\end{tabular}

TABLE $2:{ }^{13} \mathrm{C}$ NMR data of compounds I-IV.

\begin{tabular}{|c|c|c|c|c|}
\hline Carbon & ${ }^{\mathrm{a}}$ Compound I & ${ }^{\mathrm{a}}$ Compound II & ${ }^{\mathrm{a}}$ Compound III & ${ }^{\mathrm{b}}$ Compound IV \\
\hline 2 & 154.3 & 154.0 & 150.1 & 154.5 \\
\hline 3 & 122.1 & 122.6 & 124.8 & 123.0 \\
\hline 4 & 181.0 & 180.6 & 173.8 & 181.2 \\
\hline $4 a$ & 105.2 & 104.6 & 105.3 & 105.8 \\
\hline 5 & 156.6 & 159.3 & 154.3 & 157.3 \\
\hline 6 & 104.4 & 108.1 & 108.3 & 104.9 \\
\hline 7 & 155.1 & 156.8 & 151.8 & 156.4 \\
\hline 8 & 106.4 & 100.0 & 100.8 & 104.3 \\
\hline $8 \mathrm{a}$ & 154.1 & 150.1 & 153.8 & 155.3 \\
\hline $1^{\prime}$ & 121.6 & 121.5 & 122.7 & 121.7 \\
\hline $2^{\prime}$ & 119.9 & 120.0 & 114.8 & 120.4 \\
\hline $3^{\prime}$ & 145.6 & 145.6 & 130.4 & 146.2 \\
\hline $4^{\prime}$ & 144.9 & 144.9 & 157.1 & 145.4 \\
\hline $5^{\prime}$ & 116.6 & 116.6 & 130.4 & 117.0 \\
\hline $6^{\prime}$ & 115.5 & 115.4 & 114.8 & 115.9 \\
\hline $1^{\prime \prime}$ & 115.2 & 195.4 & 25.7 & 115.1 \\
\hline $2^{\prime \prime}$ & 128.7 & 86.7 & 66.6 & 129.4 \\
\hline $3^{\prime \prime}$ & 77.8 & 144.6 & 78.1 & 79.0 \\
\hline $4^{\prime \prime}$ & 27. 9 & 112.9 & 25.4 & 28.4 \\
\hline $5^{\prime \prime}$ & 27.8 & 16.7 & 20.7 & 28.1 \\
\hline $1^{\prime \prime \prime}$ & 24.3 & 127.7 & 127. 6 & 75.0 \\
\hline $2^{\prime \prime \prime}$ & 74.0 & 114.1 & 114.7 & 65.0 \\
\hline $3^{\prime \prime \prime}$ & 77.0 & 78.3 & 77.8 & 57.3 \\
\hline $4^{\prime \prime \prime}$ & 21.8 & 27.8 & 27.9 & 25.0 \\
\hline $5^{\prime \prime \prime}$ & 20.6 & 27.7 & 27.8 & 19.6 \\
\hline $\mathrm{OMe}$ & 48.6 & - & - & 56.4 \\
\hline
\end{tabular}

Data acquired at $125 \mathrm{MHz} .{ }^{\mathrm{b}}$ Data acquired at $100 \mathrm{MHz}$.

mixtures were incubated for $20 \mathrm{~min}$ at $37^{\circ} \mathrm{C}$ and stopped by the addition of $28 \mu \mathrm{L}$ of $2 \mathrm{~N} \mathrm{NaOH}$. The formation of 4 hydroxyquinoline was determined fluorometrically by Spectra Max M5 fluorescence plate reader (Molecular Devices,
Sunnyvale, CA, USA) with an excitation and emission wavelength of $320 \mathrm{~nm}$ and $380 \mathrm{~nm}$, respectively, using the Soft Max Pro program [24]. Appropriate controls were set up to check the interference with the fluorescence measurements. None 
of the tested fractions or compounds showed any interference with the fluorescence measurement. The determination of $\mathrm{IC}_{50}$ values for inhibition of MAO-A and MAO-B by the $M$. pomifera (L.) compounds was performed using a fixed concentration of the substrate and varying the concentration of the inhibitor. $M$. pomifera compounds $(0.01 \mu \mathrm{M}$ to $100 \mu \mathrm{M})$ and clorgyline $(0.001 \mu \mathrm{M}$ to $100 \mu \mathrm{M})$ for MAO-A and deprenyl $(0.001 \mu \mathrm{M}$ to $100 \mu \mathrm{M})$ for MAO-B were tested to determine $\mathrm{IC}_{50}$ from the concentration dependent inhibition curves using $\mathrm{XL}^{-\mathrm{Fit}^{(}}{ }^{(}$software.

\section{Results and Discussion}

3.1. Structural Elucidation. Compound I was obtained as a yellow solid and exhibited a sodiated molecular ion peak in HR-FTMS at $m / z 491.1690$ corresponding to the molecular formula $\mathrm{C}_{26} \mathrm{H}_{28} \mathrm{O}_{8} \mathrm{Na}$ (that calculated for $\mathrm{C}_{26} \mathrm{H}_{28} \mathrm{O}_{8} \mathrm{Na}$ is 491.1682). ${ }^{1} \mathrm{H}$ NMR (500 MHz, DMSO-d6) exhibited four methyl singlets at $\delta 1.43,1.41,1.21$, and 1.13 which were assigned to $\mathrm{H}-4^{\prime \prime}, 5^{\prime \prime}, 4^{\prime \prime \prime}$, and $5^{\prime \prime \prime}$. A singlet at $\delta 3.19$ was ascribed to the methoxy at $\mathrm{C}-3^{\prime \prime \prime}$. A doublet at $\delta$ $2.75(5.4 \mathrm{~Hz})$ was assigned to methylene protons $\mathrm{H}-1^{\prime \prime \prime}$. A multiplet integrating for one proton at $\delta 3.47$ was assigned to an oxymethine proton at $\mathrm{H}-2^{\prime \prime \prime}$. Two doublets at $\delta 5.78$ $(10.0 \mathrm{~Hz})$ and $\delta 6.63(10.0 \mathrm{~Hz})$ were assigned to $\mathrm{H}-2^{\prime \prime}$ and $1^{\prime \prime}$ methine protons. A singlet at $\delta 6.99$ and multiplet at $\delta 6.76$ were assigned to $\mathrm{H}-5^{\prime}, \mathrm{H}-2^{\prime}$, and $\mathrm{H}-6^{\prime}$. A singlet at $\delta 8.37$ was assigned to oxygenated olefinic proton $\mathrm{H}-2$.

The ${ }^{13} \mathrm{C}$ NMR data of I (125 MHz, DMSO-d6) exhibited 26 carbon atoms. Four methyls at $\delta 27.9,27.8,21.8$, and 20.6 were assigned to $\mathrm{C}-4^{\prime \prime}, \mathrm{C}-5^{\prime \prime}, \mathrm{C}-4^{\prime \prime \prime}$, and $\mathrm{C}-5^{\prime \prime \prime}$. Carbon at $\delta$ 48.6 is assigned to methoxy carbon at C-2 $2^{\prime \prime \prime}$. Carbon at $\delta 74.0$ was attributed to C-2 $2^{\prime \prime \prime}$. Two oxygenated carbon atoms at $\delta$ 77.8 and 77.0 were assigned to $3^{\prime \prime}$ and $3^{\prime \prime \prime}$. The peaks at $\delta 156.6$, $155.1,154.3,154.1,145.6$, and 144.9 were ascribed to C-5, C-7, $\mathrm{C}-2, \mathrm{C}-8 \mathrm{a}, \mathrm{C}-3^{\prime}$, and $\mathrm{C}-4^{\prime}$. The peak at $\delta 181.0$ was assigned to the carbonyl carbon at C-4. The HMBC spectrum of I showed key ${ }^{3} J$ and ${ }^{2} J$ correlations between the methoxy proton at $\delta$ 3.47 and the oxygenated methine carbon at C- $2^{\prime \prime \prime}$, confirming the position of the methoxy at C-2 $2^{\prime \prime \prime}$. COSY correlations have been noticed between $\mathrm{H}-1^{\prime \prime}$ to $\mathrm{H}-2^{\prime \prime}$ and $\mathrm{H}-1^{\prime \prime \prime}$ to $\mathrm{H}-2^{\prime \prime \prime}$. Hence, the structure of compound $\mathbf{I}$ is deduced to be $3-(3,4-$ dihydroxyphenyl)-5-hydroxy-10-(3-hydroxy-2-methoxy-3methylbutyl)-8,8-dimethylpyrano[3,2-g]chromen-4(8H)-

one (I) and named Kazosajin I.

Compound II was obtained as a yellow solid and exhibited a peak in HR-FTMS at $m / z 451.1415[\mathrm{M}-\mathrm{H}]^{-}$ corresponding to the molecular formula $\mathrm{C}_{25} \mathrm{H}_{23} \mathrm{O}_{8}$ (that calculated for $\mathrm{C}_{25} \mathrm{H}_{23} \mathrm{O}_{8}$ is 451.1393). The ${ }^{1} \mathrm{H}$ NMR (500 M $\mathrm{Hz}, \mathrm{CDCl}_{3}$ ) showed singlets at $\delta 1.46$ integrating for six protons and at $\delta 1.74$ integrating for three protons, confirming the presence of three methyls at C- $4{ }^{\prime \prime \prime}, \mathrm{C}-5^{\prime \prime \prime}$, and $\mathrm{C}-5^{\prime \prime}$. A downfield singlet at $\delta 4.52$ (s) was ascribed to the $\mathrm{H}-2^{\prime \prime}$. Two singlets at $\delta 4.77$ and 4.67 were assigned to exomethylene protons $\mathrm{H}-4^{\prime \prime}$. Two doublets at $\delta 6.66(10.0 \mathrm{~Hz})$ and $5.77(10.0 \mathrm{~Hz})$ were assigned to the two olefinic protons at $\mathrm{H}-1^{\prime \prime \prime}$ and $\mathrm{H}-2^{\prime \prime \prime}$. Two doublets at $\delta 6.93(1.8 \mathrm{~Hz})$ and 6.79 $(1.8 \mathrm{~Hz})$ and a singlet at $\delta 7.00$ were assigned to trisubstituted benzene ring protons at $\mathrm{H}-6^{\prime}, \mathrm{H}-5^{\prime}$, and $\mathrm{H}-2^{\prime}$. An oxygenated olefinic proton $\mathrm{H}-2$ appeared as a singlet at $\delta 8.31 .{ }^{13} \mathrm{C} \mathrm{NMR}$ $\left(125 \mathrm{MHz}, \mathrm{CDCl}_{3}\right)$ of II exhibited 26 carbon atoms. It showed three methyls at $\delta$ 27.9, 27.7, and 16.7 which were attributed to $\mathrm{C}-4^{\prime \prime \prime}, \mathrm{C}-5^{\prime \prime \prime}$, and $\mathrm{C}-5^{\prime \prime}$. Methine carbon at $\delta 86.7$ and quaternary carbon at 78.3 were assigned to C- $2^{\prime \prime}$ and C- $3^{\prime \prime \prime}$. The peaks at $\delta 159.3,156.8,154.0,150.8,145.6$, and 144.9 were ascribed to the oxygenated carbon atoms at C-5, C-7, C-2, $\mathrm{C}-8 \mathrm{a}, \mathrm{C}-3^{\prime}$, and $\mathrm{C}-4^{\prime}$. The peaks at $\delta 195.4$ and 181.2 were ascribed to carbonyls at C-1" and C-3. The HMBC spectrum of II showed ${ }^{3} J$ and ${ }^{2} J$ correlations between the $\mathrm{H}-5^{\prime \prime}$ and $\mathrm{C}-2^{\prime \prime}, \mathrm{C}-3^{\prime \prime}$, and $\mathrm{C}-4^{\prime \prime}$, and $\mathrm{H}-2^{\prime \prime}$ with $\mathrm{C}-1^{\prime \prime}$ indicated the presence of a prenylated side chain with $\alpha$-hydroxy ketone. Hence, the structure of compound II is deduced to be 3-(3,4dihydroxyphenyl)-5-hydroxy-6-(2-hydroxy-3-methylbut-3enoyl)-8,8-dimethylpyrano[2,3-f]chromen-4(8H)-one and named Kazosajin II.

Compound III was obtained as a yellow solid and exhibited a molecular ion peak in HR-FTMS at $m / z 421.1649$ corresponding to the molecular formula $\mathrm{C}_{25} \mathrm{H}_{25} \mathrm{O}_{6}$ (that calculated for $\mathrm{C}_{25} \mathrm{H}_{25} \mathrm{O}_{6}$ is 421.1651). The spectral data of III is similar to that of iso-osajin except for the hydroxylation at C- $2^{\prime \prime} \cdot{ }^{1} \mathrm{H}$ NMR (400 M Hz, DMSO-d6) showed five singlets at $\delta 1.45$, $1.44,1.30$, and 1.20 assigned to $\mathrm{H}-4^{\prime \prime}, \mathrm{H}-5^{\prime \prime}, \mathrm{H}-4^{\prime \prime \prime}$, and $\mathrm{H}-5^{\prime \prime \prime}$. Two resonances at $\delta 2.79(\mathrm{dd}, 5.3,17.0 \mathrm{~Hz})$ and $\delta 2.43(\mathrm{dd}, 7.3$, $17.0 \mathrm{~Hz})$ are attributed to $\mathrm{H}_{2}-1^{\prime \prime}$. The triplet at $\delta 3.66(6.3 \mathrm{~Hz})$ was ascribed to oxymethine proton at $\mathrm{H}-2^{\prime \prime}$. The two doublets at $\delta 5.73(9.9 \mathrm{~Hz})$ and $6.68(9.9 \mathrm{~Hz})$ are assigned to the olefinic protons $\mathrm{H}-1^{\prime \prime \prime}$ and $\mathrm{H}-2^{\prime \prime \prime}$. The two doublets at $\delta 6.79$ (8.4) and $7.30(8.4)$ were ascribed to four aromatic protons $\mathrm{H}-2^{\prime}$, $\mathrm{H}-3^{\prime}, \mathrm{H}-5^{\prime}$, and $\mathrm{H}-6^{\prime}$ on a $p$-disubstituted benzene ring. A singlet at 8.10 was assigned to oxygenated olefinic proton $\mathrm{H}-2 .{ }^{13} \mathrm{C}$ NMR (100 MHz, DMSO-d6) of III exhibited 25 carbon atoms. It showed four methyls at 27.9, 27.8, 25.4, and 20.7 attributed to C- $4^{\prime \prime \prime}, \mathrm{C}-5^{\prime \prime \prime}, \mathrm{C}-4^{\prime \prime}$, and C-5 $5^{\prime \prime}$. It showed three $\mathrm{sp}^{3}$ oxygenated carbon atoms at $\delta 78.1,77.8$, and 66.6 which were assigned to $\mathrm{C}-3^{\prime \prime}, \mathrm{C}-3^{\prime \prime \prime}$, and C- $2^{\prime \prime}$, respectively. It exhibited five oxygenated aromatic carbon atoms at $\delta$ 157.1, $154.3,153.8,151.8$, and 150.1 which were assigned to $\mathrm{C}-4^{\prime}$, C-5, C-8a, C-7, and C-2. The peak at $\delta 173.8$ was ascribed to the carbonyl carbon at C-3. The HMBC spectrum of III showed ${ }^{3} J$ and ${ }^{2} J$ correlations between the methyl protons at $\mathrm{H}-4^{\prime \prime}, 5^{\prime \prime}$ to $\mathrm{C}-2^{\prime \prime}$, and $3^{\prime \prime}$ indicating the presence of a hydroxyl group at C- $2^{\prime \prime}$. Hence, the structure of compound III is deduced to be 11-hydroxy-7-(4-hydroxyphenyl)2,2,10,10-tetramethyl-11,12-dihydro-2H-dipyrano[2,3-f: $2^{\prime}, 3^{\prime}$ h]chromen-8(10H)-one (III) and named Kazosajin III.

Compound IV was obtained as a yellow solid and exhibited a peak in HR-FTMS at $m / z 465.1466[\mathrm{M}-\mathrm{H}]^{-}$ corresponding to the molecular formula $\mathrm{C}_{26} \mathrm{H}_{26} \mathrm{O}_{8}$ (that calculated for $\mathrm{C}_{26} \mathrm{H}_{25} \mathrm{O}_{8}$ is 465.1549$)$. ${ }^{1} \mathrm{H}$ NMR (400 M Hz, $\mathrm{CDCl}_{3}$ ) showed four singlets at $\delta 1.44,1.43,1.19$, and 1.06 for the presence of four methyls at C- $4^{\prime \prime}, \mathrm{C}-5^{\prime \prime}, \mathrm{C}-4^{\prime \prime \prime}$, and $\mathrm{C}-5^{\prime \prime \prime}$. A downfield singlet at $\delta 3.22$ was ascribed to the methoxy protons at C-1 $1^{\prime \prime \prime}$. Two doublets at $\delta 4.54(7.3 \mathrm{~Hz})$ and $3.65(7.3 \mathrm{~Hz})$ were assigned to oxymethine protons $\mathrm{H}-1^{\prime \prime \prime}$ and $\mathrm{H}-2^{\prime \prime \prime}$ and the two doublets at $\delta 6.63(10.0 \mathrm{~Hz})$ and 5.82 $(10.0 \mathrm{~Hz})$ were assigned to two olefinic protons at $\mathrm{H}-\mathrm{l}^{\prime \prime}$ and $\mathrm{H}-2^{\prime \prime}$. A singlet at $\delta 6.81$ and two doublets at $\delta 7.03(1.9 \mathrm{~Hz})$ 
TABLE 3: Cannabinoid receptors activity of potential constituents $(10 \mu \mathrm{M})$ from M. pomifera.

\begin{tabular}{|c|c|c|c|c|c|c|}
\hline \multirow{2}{*}{ Compound } & \multicolumn{3}{|c|}{ CB1 } & \multicolumn{3}{|c|}{ CB2 } \\
\hline & $\%$ displacement & $\mathrm{IC}_{50}(\mu \mathrm{M})$ & $K i(\mu \mathrm{M})$ & $\%$ displacement & $\mathrm{IC}_{50}(\mu \mathrm{M})$ & $K i(\mu \mathrm{M})$ \\
\hline Pomiferin $(\mathbf{V})$ & 107.2 & 2.110 & 1.055 & 66.0 & 1.318 & 6.590 \\
\hline Auriculasin (VI) & 86.7 & 8.923 & 4.462 & - & - & - \\
\hline Warangalone (VII) & 111.3 & 1.670 & 8.350 & 77.6 & 4.438 & 2.219 \\
\hline Osajin (VIII) & 93.9 & 3.859 & 1.929 & 52.7 & 7.646 & 3.823 \\
\hline
\end{tabular}

TABLE 4: Inhibition of recombinant human monoamine oxidase-A and monoamine oxidase-B of I-VIII from M. pomifera.

\begin{tabular}{lccc}
\hline Compounds & $\begin{array}{c}\text { Monoamine oxidase-A IC } \\
(\mu \mathrm{M})\end{array}$ & $\begin{array}{c}\text { Monoamine oxidase-B } \\
\mathrm{IC}_{50}(\mu \mathrm{M})\end{array}$ & $\begin{array}{c}\text { SI index } \\
\mathrm{MAO}-\mathrm{A} / \mathrm{B}\end{array}$ \\
\hline Kazosajin I & $74.33 \pm 3.44$ & $11.59 \pm 1.39$ & $\mathbf{4 . 2 8} \pm \mathbf{0 . 6 7}$ \\
Kazosajin II & $72.03 \pm 3.72$ & $\mathbf{7 . 1 6} \pm \mathbf{1 . 1 5}$ & 16.813 \\
Kazosajin III & $>100$ & $17.66 \pm 1.06$ & - \\
Kazosajin IV & $71.20 \pm 2.61$ & $>100$ & 4.032 \\
Pomiferin (V) & $>100$ & $\mathbf{1 . 9 1} \pm \mathbf{0 . 3 2}$ & - \\
Auriculasin (VI) & $45.98 \pm 4.48$ & $\mathbf{5 . 6 9} \pm \mathbf{0 . 3 8}$ & - \\
Warangalone (VII) & $>100$ & $>100$ & - \\
Osajin (VIII) & $>100$ & - & - \\
Clorgyline & $0.0045 \pm 0.0004$ & $0.0326 \pm 0.012$ & - \\
Deprenyl & - &
\end{tabular}

Notes. The results of $\mathrm{IC}_{50}$ values are expressed as mean $\pm \mathrm{SD}$ of triplicate observations.

and $6.80(1.9 \mathrm{~Hz})$ were assigned to the three aromatic protons at $\mathrm{H}-2^{\prime}, \mathrm{H}-5^{\prime}$, and $\mathrm{H}-6^{\prime}$. An oxygenated olefinic proton $\mathrm{H}-2$ appeared as a singlet at $\delta 8.42 .{ }^{13} \mathrm{C} \mathrm{NMR}\left(100 \mathrm{MHz}, \mathrm{CDCl}_{3}\right)$ of IV exhibited 26 carbon atoms. It showed four methyls at $\delta 28.4,28.1,25.0$, and 19.6 attributed to C- $4^{\prime \prime}, \mathrm{C}-5^{\prime \prime}, \mathrm{C}-4^{\prime \prime \prime}$, and $C-5^{\prime \prime \prime}$. Downfield methyl carbon at $\delta 56.4$ was assigned to the methoxy carbon at $\mathrm{C}-1^{\prime \prime \prime}$. The four $\mathrm{sp}^{3}$ oxygenated carbon atoms at $\delta 75.0,65.0,79.0$, and 57.3 were assigned to $\mathrm{C}-1^{\prime \prime \prime}, \mathrm{C}-2^{\prime \prime \prime}, \mathrm{C}-3^{\prime \prime}$, and C-3 ${ }^{\prime \prime \prime}$. The peaks at $\delta 157.3,156.4$, $155.3,154.5,146.2$, and 145.4 were ascribed to the oxygenated $\mathrm{sp}^{2}$ carbon atoms at C-5, C-7, C-8a, C-2, C-3', and C- $4^{\prime}$. The peak at $\delta 181.2$ was ascribed to the carbonyl at C-3. The HMBC spectrum of IV showed ${ }^{3} J$ and ${ }^{2} J$ correlations between the methyl protons at $\mathrm{H}-4^{\prime \prime \prime}$ and $5^{\prime \prime \prime}$ to $\mathrm{C}-2^{\prime \prime \prime}$ and $3^{\prime \prime \prime}$ indicating the presence of an epoxy system between C-2 $2^{\prime \prime \prime}$ and C- $3^{\prime \prime \prime}$ which was further confirmed by HRMS. Hence, the structure of compound IV is deduced to be $3-(3,4-$ dihydroxyphenyl)-10-((3,3-dimethyloxiran-2-yl)(methoxy) methyl)-5-hydroxy-8,8-dimethylpyrano[3,2-g]chromen$4(8 \mathrm{H})$-one (IV) and named Kazosajin IV.

Compounds V-XV were isolated and identified by comparing their NMR data with the literature to be pomiferin (V) [16], auriculasin (VI) [16], warangalone (VII) [17], osajin (VIII) [16], artocarpesin (IX) [16], tonkinensisol (X) [18], corchoionoside B (XI) [19], kaempferol-7- $O-\beta-D$ glucoside (XII) [16], dihydrokaempferol-7-O- $\beta$ - $D$-glucoside (XIII) [16], stigmasterol (XIV), and $\beta$-sitosterol (XV).

3.2. Cannabinoid and Opioid Receptors Assay. The affinities of the total extracts and the isolated compounds towards cannabinoid and opioid receptors were assessed using
CP-55940 and Naloxone as controls for cannabinoid and opioid receptors assays, respectively. The total extract showed significant activity towards cannabinoid receptor (CB1: 103.4\% displacement; CB2: $68.8 \%$ displacement), possibly allosteric towards $\delta$ and $\mu$ opioid receptors ( -49.7 and $-53.8 \%$ displacement, resp.). The new compound Kazosajin I was found to be possibly an allosteric compound in $\kappa$ and $\mu$ opioid receptors ( -88.4 and $-27.2 \%$ displacement, resp.). Kazosajin II exhibited moderate activity towards cannabinoid receptors (CB1: 47.9\% displacement; CB2: $42.3 \%$ displacement). The known compounds-pomiferin (V) (CB1: 107.2\% displacement; CB2: $66.0 \%$ displacement), osajin (VIII) (CB1: 93.9\% displacement; CB2: 52.7\% displacement), and warangalone (VII) (CB1: 111.3\% displacement; CB2: $77.57 \%$ displacement) — exhibited prominent activity towards cannabinoid receptors. The $\mathrm{IC}_{50}$ and $K i$ values for $\mathrm{CB} 1$ and $\mathrm{CB} 2$ receptors active compounds are given in Table 3.

3.3. Determination of the Inhibitory Effect of $M$. pomifera (L.) Compounds on Recombinant Human MAO-A and MAO-B. The compounds isolated from $M$. pomifera (L.) fruits were tested for their inhibitory effect against recombinant human $\mathrm{MAO}$ isoforms (MAO-A and MAO-B) in vitro. The enzymatic activity of MAO-A and MAO - B was determined via a fluorescence based method [24]. All the tested compounds showed fewer inhibitory effects on MAO-A compared to MAO-B activities (Table 4).

\section{Conclusions}

The Maclura pomifera total extract of the fruits showed significant activity towards cannabinoid receptors and possibly 
allosteric interactions with $\delta$ and $\mu$ opioid receptors [25]. Four new compounds (I-IV) along with eleven known compounds $(\mathbf{V}-\mathbf{X V})$ were isolated and identified from the extract. The new compound Kazosajin I was found to be possibly allosteric towards $\kappa$ and $\mu$ opioid receptors, while the new compound Kazosajin II exhibited moderate activity towards cannabinoid receptors CB1 and CB2. Compounds V, VII, and VIII exhibited prominent activity towards cannabinoid receptors. All the isolated compounds from $M$. pomifera (L.) fruits were tested for their inhibitory effect against recombinant human MAO isoforms (MAO-A and MAO-B) in vitro, where four compounds (II, III, VI, and VII) showed selective inhibition of MAO-B. All the tested compounds showed fewer inhibitory effects on MAO-A compared to MAO-B activities.

\section{Disclosure}

The content is solely the responsibility of the authors and does not necessarily represent the official views of the National Institute of General Medical Sciences or the National Institutes of Health, USA. This work has been presented at GA 2017 Conference, Basel, Switzerland [25].

\section{Conflicts of Interest}

The authors declare no conflicts of interest.

\section{Acknowledgments}

This project was supported by Kazakhstan government and the National Center for Natural Products Research, University of Mississippi, USA. The bioassays were conducted at the in vitro neuropharmacological core supported by the National Institute of General Medical Sciences (Award no. P20GM104932). The authors wish to thank Drs. Joshua Sharp and Sandeep Misra for FTMS-ESI, Janet A. Lambert for the CB1/CB2 assays, and Dr. Mohamed Abo Elmagd for his assistance with the laboratory work.

\section{Supplementary Materials}

1D and 2D NMR and mass data for compounds I- IV; this material is available free of charge via the Internet through the journal's website. Figure S1: ${ }^{1} \mathrm{H}$ NMR spectrum for compound I (DMSO-d6, $500 \mathrm{MHz}$ ). Figure S2: ${ }^{13} \mathrm{C}$ NMR spectrum for compound I (DMSO-d6, $125 \mathrm{MHz}$ ). Figure S3: DEPT spectrum for compound I (DMSO-d6, $125 \mathrm{MHz}$ ). Figure S4: HSQC spectrum for compound I (DMSO-d6, $500 \mathrm{MHz}$ ). Figure S5: HMBC spectrum for compound I (DMSO-d6, $500 \mathrm{MHz}$ ). Figure S6: COSY spectrum for compound I (DMSO-d6, $500 \mathrm{MHz}$ ). Figure S7: FTMS spectrum for compound I. Figure S8: ${ }^{1} \mathrm{H}$ NMR spectrum for compound II (DMSO- d6, $500 \mathrm{MHz}$ ). Figure S9: ${ }^{13} \mathrm{C}$ NMR spectrum for compound II (DMSO-d6, $125 \mathrm{MHz}$ ). Figure S10: DEPT spectrum for compound II (DMSO-d6, 125 MHz). Figure S11: HSQC spectrum for compound II (DMSO-d6, $500 \mathrm{MHz}$ ). Figure S12: HMBC spectrum for compound II (DMSO-d6,
$500 \mathrm{MHz}$ ). Figure S13: FTMS spectrum for compound II. Figure S14: ${ }^{1} \mathrm{H}$ NMR spectrum for compound III (DMSOd6, $500 \mathrm{MHz}$ ). Figure S15: ${ }^{13} \mathrm{C}$ NMR spectrum for compound III (DMSO-d6, $125 \mathrm{MHz}$ ). Figure S17: HSQC spectrum for compound III (DMSO-d6, $500 \mathrm{MHz}$ ). Figure S18: HMBC spectrum for compound III (DMSO-d6, $500 \mathrm{MHz}$ ). Figure S19: FTMS spectrum for compound III. Figure S20: ${ }^{1} \mathrm{H}$ NMR spectrum for compound IV (DMSO-d6, $400 \mathrm{MHz}$ ). Figure S21: ${ }^{13} \mathrm{C}$ NMR spectrum for compound IV (DMSOd6, $100 \mathrm{MHz}$ ). Figure S22: DEPT spectrum for compound IV (DMSO-d6, $100 \mathrm{MHz}$ ). Figure S23: HSQC spectrum for compound IV (DMSO-d6, $400 \mathrm{MHz}$ ). Figure S24: HMBC spectrum for compound IV (DMSO-d6, $400 \mathrm{MHz}$ ). Figure S25: COSY spectrum for compound IV (DMSO-d6, $400 \mathrm{MHz}$ ). Figure S26: NOESY spectrum for compound IV (DMSO-d6, $400 \mathrm{MHz}$ ). Figure S27: FTMS spectrum for compound IV. (Supplementary Material)

\section{References}

[1] F. Saloua, N. I. Eddine, and Z. Hedi, "Chemical composition and profile characteristics of Osage orange Maclura pomifera (Rafin.) Schneider seed and seed oil," Industrial Crops and Products, vol. 29, no. 1, pp. 1-8, 2009.

[2] J. M. Jones and F. Soderberg, "Cytotoxicity of lymphoid cells induced by Maclura pomifera (MP) lectin," Cellular Immunology, vol. 42, no. 2, pp. 319-326, 1979.

[3] G. Bourdy, L. R. Chavez De Michel, and A. Roca-Coulthard, "Pharmacopoeia in a shamanistic society: the Izoceño-Guaraní (Bolivian Chaco)," Journal of Ethnopharmacology, vol. 91, no. 23, pp. 189-208, 2004.

[4] G. G. Carlson and H. J. Volney, "Some notes on uses of plants by the Comanche Indians. Papers of the Michigan Academy of Science," Papers of Michigan Academy of science Arts and Letters, vol. 25, pp. 517-542, 1939.

[5] C. F. Peterson and E. W. Brockemeyer, "The anti-fungal activity of an aqueous extract of osage orange wood," American Journal of Pharmacy and the Sciences Supporting Public Health, vol. 125, no. 9, pp. 303-310, 1953.

[6] Z. F. Mahmoud, "Antimicrobial components from Maclura pomifera fruit," Planta Medica, vol. 42, no. 3, pp. 299-301, 1981.

[7] E. Voynova, S. Dimitrova, E. Naydenova, and P. Karadjov, "Inhibitory action of extracts of Maclura aurantiaca and Epilobium hirsutum on tumour models in mice," Acta Physiologica et Pharmacologica Bulgarica, vol. 17, no. 4, pp. 50-52, 1991.

[8] C. G.-A. Maier, K. D. Chapman, and D. W. Smith, "Differential estrogenic activities of male and female plant extracts from two dioecious species," Journal of Plant Sciences, vol. 109, no. 1, pp. 31-43, 1995.

[9] N. Bunyapraphatsara, S. Dechsree, C. Yoosook, A. Herunsalee, and Y. Panpisutchai, "Anti-herpes simplex virus component isolated from Maclura cochinchinensis," Phytomedicine : international journal of phytotherapy and phytopharmacology, vol. 6, no. 6, pp. 421-424, 2000.

[10] A.-E. Hay, J.-J. Hélesbeux, O. Duval, M. Labaïed, P. Grellier, and P. Richomme, "Antimalarial xanthones from Calophyllum caledonicum and Garcinia vieillardii," Life Sciences, vol. 75, no. 25, pp. 3077-3085, 2004.

[11] C. Kerem, E. B. Mustafa, and A. Ergin, "In Vitro antimicrobial activity screening of maclura pomifera fruits against wide range 
of microorganisms," International Journal of Pharmaceutical Science Invention, vol. 6, no. 8, pp. 19-22, 2017.

[12] E. Kupeli, I. Orhan, G. Toker, and E. Yesilada, "Anti-inflammatory and antinociceptive potential of Maclura pomifera (Rafin.) Schneider fruit extracts and its major isoflavonoids, scandenone and auriculasin," Journal of Ethnopharmacology, vol. 107, no. 2, pp. 169-174, 2006.

[13] I. Orhan, F. S. Şenol, M. Kartal et al., "Cholinesterase inhibitory effects of the extracts and compounds of Maclura pomifera (Rafin.) Schneider," Food and Chemical Toxicology, vol. 47, no. 8, pp. 1747-1751, 2009.

[14] "Bois d'arc fruit may hold key to Alzheimer's," https://news .tamus.edu/bois-darc-fruit-may-hold-key-to-alzheimers/ Texas A\&M University, March 1, 2006. Retrieved December 28, 2015.

[15] K. Sasaki, Y. Tsurumaru, H. Yamamoto, and K. Yazaki, "Molecular characterization of a membrane-bound prenyltransferase specific for isoflavone from Sophora flavescens," The Journal of Biological Chemistry, vol. 286, no. 27, pp. 24125-24134, 2011.

[16] G. D. Monache, R. Scurria, A. Vitali et al., "Two isoflavones and a flavone from the fruits of Maclura pomifera," Phytochemistry, vol. 37, no. 3, pp. 893-898, 1994.

[17] E. Talla, D. Njamen, J. T. Mbafor et al., "Warangalone, the isoflavonoid anti-inflammatory principle of Erythrina addisoniae stem bark," Journal of Natural Products, vol. 66, no. 6, pp. 891-893, 2003.

[18] Y.-H. Deng, K.-P. Xu, Y.-J. Zhou, F.-S. Li, G.-Y. Zeng, and G.S. Tan, "A new flavonol from Sophora tonkinensis," Journal of Asian Natural Products Research, vol. 9, no. 1, pp. 45-48, 2007.

[19] M. Yoshikawa, H. Shimada, M. Saka, S. Yoshizumi, J. Yamahara, and H. Matsuda, "Medicinal foodstuffs. V. Moroheiya. (1): Absolute stereostructures of corchoionosides A, B, and C, histamine release inhibitors from the leaves of Vietnamese Corchorus olitorius L. (Tiliaceae)," Chemical \& Pharmaceutical Bulletin, vol. 45, no. 3, pp. 464-469, 1997.

[20] A. Tarawneh, F. León, S. Pettaway et al., "Flavonoids from Perovskia atriplicifolia and Their in Vitro Displacement of the Respective Radioligands for Human Opioid and Cannabinoid Receptors," Journal of Natural Products, vol. 78, no. 6, pp. 14611465, 2015.

[21] V. Samoylenko, M. M. Rahman, B. L. Tekwani et al., "Banisteriopsis caapi, a unique combination of MAO inhibitory and antioxidative constituents for the activities relevant to neurodegenerative disorders and Parkinson's disease," Journal of Ethnopharmacology, vol. 127, no. 2, pp. 357-367, 2010.

[22] N. D. Chaurasiya, V. Gogineni, K. M. Elokely et al., "Isolation of acacetin from Calea urticifolia with inhibitory properties against human monoamine oxidase-A and -B," Journal of Natural Products, vol. 79, no. 10, pp. 2538-2544, 2016.

[23] N. D. Chaurasiya, M. A. Ibrahim, I. Muhammad, L. A. Walker, and B. L. Tekwani, "Monoamine oxidase inhibitory constituents of propolis: kinetics and mechanism of inhibition of recombinant human MAO-A and MAO-B," Molecules, vol. 19, no. 11, pp. 18936-18952, 2014.

[24] S. Parikh, S. Hanscom, P. Gagne, C. Crespi, and C. Patten, "A fluorescent-based, high-throughput assay for detecting inhibitors of human monoamine oxidase A and B," in S02T081R2, Biosciences Discovery Labware, Woburn, MA, USA, 2002.

[25] S. Ross, Y. Orazbekov, R. Srivedavyasasri, S. Mombekov, U. Datkhayev, and B. Makhatov, "Isolation and biological evaluation of prenylated flavonoids from Maclura pomifera," in Proceedings of the GA 2017 - Book of Abstracts, Basel, Switzerland, September 2017, https://coms.events/GA2017/ data/abstracts/en/abstract_0266.html. 


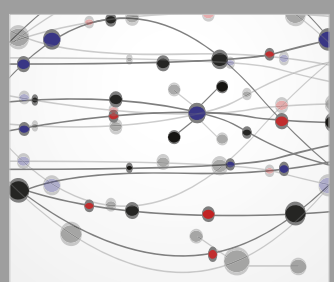

The Scientific World Journal
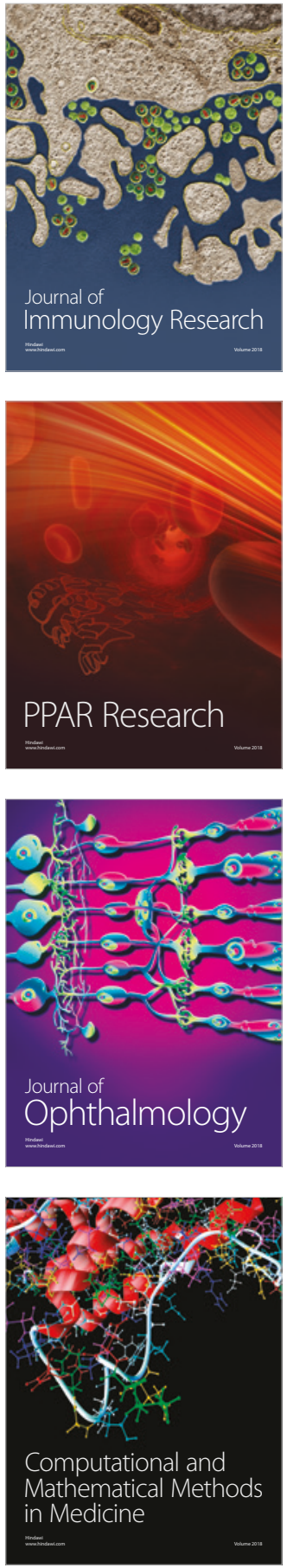

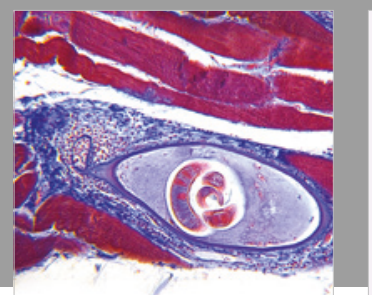

Gastroenterology Research and Practice

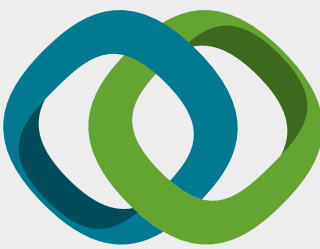

\section{Hindawi}

Submit your manuscripts at

www.hindawi.com
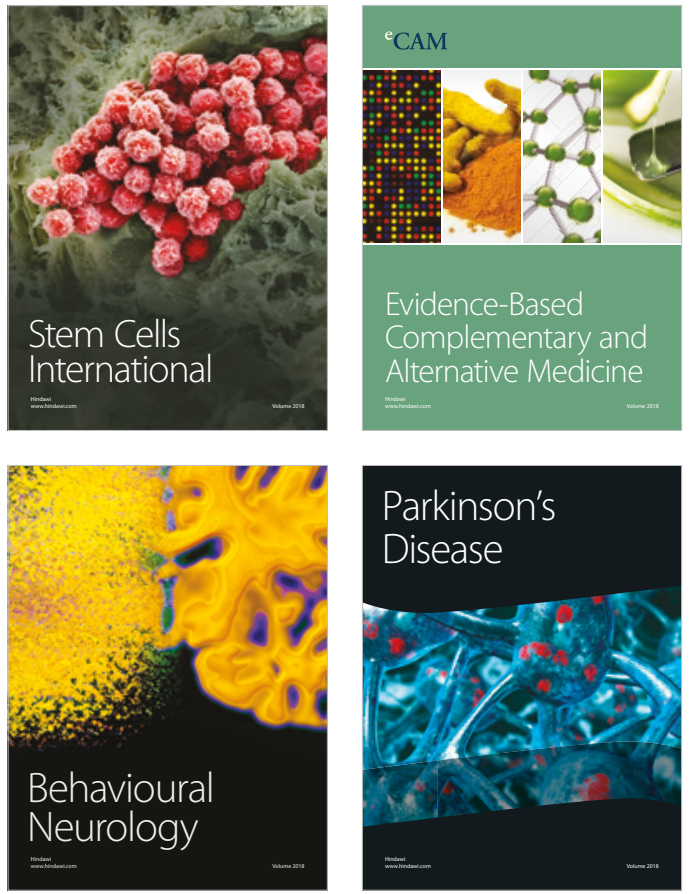

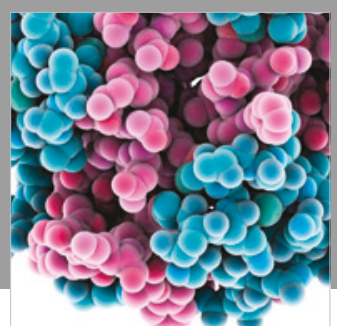

ournal of

Diabetes Research

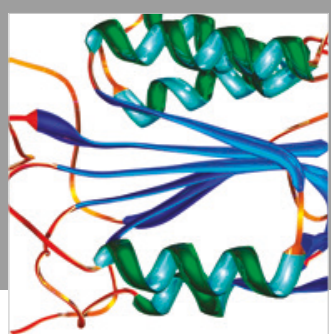

Disease Markers
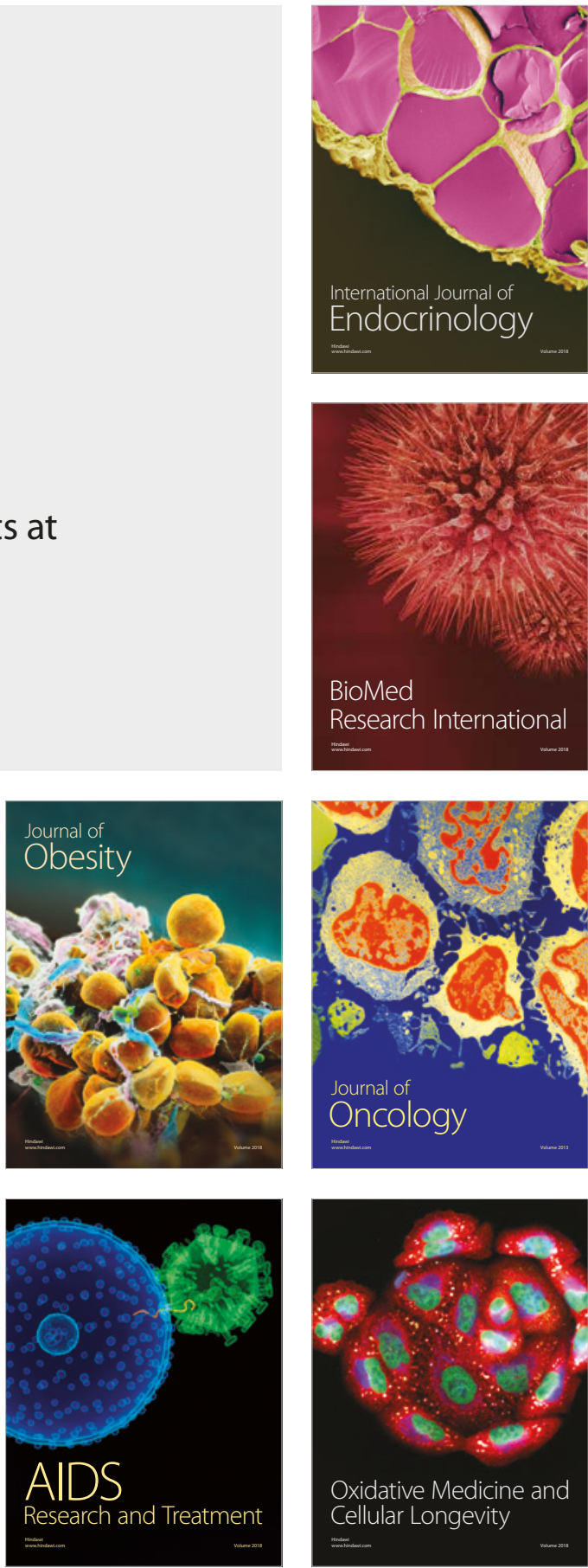